\title{
Eliza Kosieradzka
}

Uniwersytet Marii Curie-Skłodowskiej w Lublinie

eliza.kosieradzka@poczta.umcs.lublin.pl

\section{Marian Zdyb}

Uniwersytet Marii Curie-Skłodowskiej w Lublinie

zdybm@wp.pl

\section{Zasada państwa prawnego na gruncie prawa administracyjnego w kontekście współczesnych wyzwań}

\section{The Principle of the State of Law on the Basis of Administrative Law in the Context of Present-Day Challenges}

\section{STRESZCZENIE}

Problematyka zasad prawa administracyjnego ma znaczenie fundamentalne, a zarazem wywołuje wiele sporów i dyskusji, które dotyczą: samego pojęcia „zasady prawa”, charakteru tych zasad, stopnia ich ogólności, ich funkcji, zadań i roli dla prawa administracyjnego, ich istoty czy też odpowiedniej ich klasyfikacji. W ramach niniejszego opracowania odniesiono się do wszystkich wymienionych kwestii, przy czym za wymagającą szczególnego wyróżnienia na gruncie prawa administracyjnego uznano zasadę państwa prawnego. Stanowi ona pomost między dobrem wspólnym i godnością człowieka, swoisty łącznik pomiędzy innymi zasadami ładu publicznego, który można ujmować $\mathrm{w}$ aksjologicznej perspektywie. Zasada ta jest jedną $\mathrm{z}$ aksjologicznych podstaw dla właściwej interpretacji zasad ogólnych kodeksu postępowania administracyjnego. Może też dawać podstawę do kreowania prawa do dobrej administracji. Zasada ta ma wyjątkowe znaczenie dla kształtowania ładu publicznego w sferze prawa administracyjnego, a powinna być również symbolem ładu publicznego ujmowanego wielopłaszczyznowo.

Słowa kluczowe: państwo prawa; porządek publiczny; dobro wspólne; godność jednostki; prawo do dobrej administracji

\section{ISTOTA I CHARAKTERYSTYKA OGÓLNA ZASAD PRAWA ADMINISTRACYJNEGO}

W doktrynie prawa administracyjnego podkreśla się, że problematyka zasad prawa należy do zagadnień o znaczeniu fundamentalnym, a jednocześnie do za- 
gadnień kontrowersyjnych, wywołujących spory i dyskusje, które koncentrują się przede wszystkim na takich kwestiach, jak: 1) samo pojęcie ,zasady prawa”, 2) charakter normatywny zasad, 3) stopień ogólności zasad, 4) funkcje zasad (zadania, rola zasad dla prawa administracyjnego), 5) ośrodki formułowania zasad prawa administracyjnego/źródła zasad prawa administracyjnego, 6) istota zasad prawa administracyjnego czy 7) katalog zasad (typologia zasad).

Jak wspomniano, pojęcie „zasada prawa” jest przez doktrynę prawa uznawane za kontrowersyjne. Chodzi tutaj m.in. o kwestię samego ich „dookreślenia”, mowa jest bowiem zarówno o „zasadach prawa” jako takich, „zasadach systemu prawa”, „zasadach części systemu prawa”, „zasadach ogólnych”, ,podstawowych zasadach prawa”, jak i o „ogólnych ideach”, „,wartościach ogólnych”, „regułach”, „postulatach" itd. ${ }^{1}$ Wskazuje się przy tym często na poglądy doktryny teorii prawa, traktując je jako - w zakresie koncepcji zasad prawa - modelowe ${ }^{2}$. Należy przy tym zaznaczyć, że rozumienie tego pojęcia na gruncie poglądów doktryny prawa administracyjnego zasadniczo nie różni się od jego rozumienia przez teoretyków prawa. T. Gizbert-Studnicki, zwracając uwagę na kontrowersje wokół pojęcia zasady prawnej, stwierdził:

Szczególnie w dogmatyce prawniczej pojęcie to występuje w wielu różnorodnych znaczeniach. W pracach teoretycznoprawnych dogmatyczne ujęcia zasad są porządkowane i precyzowane w celu zbudowania adekwatnej aparatury pojęciowej, za pomocą której miejsce zasad w systemie prawa $\mathrm{i}$ ich funkcje $\mathrm{w}$ procesie tworzenia i stosowania prawa mogłyby zostać sprawnie opisane. Punktem wyjścia teoretycznoprawnych koncepcji zasad prawnych są więc ujęcia zasad explicite formułowane bądź też tylko implicite zakładane w dogmatyce prawniczej³

Pod pojęciem „zasada prawa” rozumie się, po pierwsze, normy prawa obowiązującego lub ich logiczne konsekwencje, które są oceniane jako podstawowe dla danego systemu prawa bądź jego części ${ }^{4}$. O zasadniczym charakterze takiej

${ }^{1}$ Zob. np. E. Olejniczak-Szałowska, Pojęcie, cechy i typologia zasad prawa administracyjnego, [w:] Prawo administracyjne. Pojęcia, instytucje, zasady w teorii i orzecznictwie, red. Z. Duniewska [et al.], Warszawa 2013, s. 112; M. Stahl, Wplyw zasad ogólnych na przeksztatcenia ustrojowe w administracji publicznej. Zagadnienia wybrane, [w:] Ewolucja prawnych form administracji publicznej. Księga jubileuszowa z okazji 60. rocznicy urodzin Profesora Ernesta Knosali, red. L. Zacharko, A. Matan, G. Łaszczyca, Warszawa 2008, s. 239.

${ }^{2}$ Zob. np. E. Olejniczak-Szałowska, op. cit., s. 112 i n.; K. Ziemski, Zasady ogólne prawa administracyjnego, Poznań 1989, s. 23 i n.; E. Ura, E. Ura, Prawo administracyjne, Warszawa 1999, s. 61-62.

${ }^{3}$ T. Gizbert-Studnicki, Zasady i reguly prawne, „Państwo i Prawo” 1988, z. 3, s. 16.

${ }^{4}$ Por. np. J. Wróblewski, Prawo obowiazujące a „ogólne zasady prawa”, „Zeszyty Naukowe Uniwersytetu Łódzkiego. Nauki Humanistyczno-Społeczne. Seria I” 1965, z. 42, s. 17-38; S. Wronkowska, Z. Ziembiński, Zarys teorii prawa, Poznań 2001, s. 185-189, 79-80. Z nowszej literatury przedmiotu zob. M. Kordela, Zasady prawa. Studium teoretycznoprawne, Poznań 2012. Zob. także: A. Pułło, Z problematyki zasad prawa: idee ogólne w prawie konstytucyjnym, „Przegląd Sejmowy” 1996, nr 1(13), s. 9-20. 
normy, jak wskazuje Z. Kmieciak, decyduje: „1) jej usytuowanie w hierarchicznej strukturze systemu prawa, 2) stosunek do innych norm, 3) rola w kształtowaniu danej instytucji prawnej, 4) ocena celu, zadań i funkcji pełnionych przez normę w kontekście jej stosowania"s. Jednocześnie podkreśla on, że w sensie normatywnym mówi się o zasadach prawa administracyjnego w odniesieniu do reguł wynikających z przepisów konstytucyjnych albo rekonstruowanych na podstawie innych przepisów, które wchodzą w skład systemu prawa, przy uwzględnieniu ich treści ${ }^{6}$.

K. Ziemski określa natomiast formalne i materialne przesłanki uznawania norm za zasadnicze. Do przesłanek formalnych zaliczył on: 1) określenie explicite przez prawodawcę, że pewne normy mają znaczenie zasadnicze (np. zasady ogólne k.p.a.), 2) rangę aktu prawnego, w jakim normy te zostały wyrażone, 3) takie ujęcie tych norm w ramach aktu prawnego, które przesądza o ich roli wobec innych norm w tym akcie, a czasem także wobec innych norm wyrażonych w akcie wykonawczym, 4) szczególnie szeroki zakres normowania, 5) szczególnie szeroki zakres zastosowania danych dyrektyw. Z kolei do przesłanek materialnych zaliczył: 1) „fakt, że dana dyrektywa wyznacza elementy systemu preferencji, w którym znajdować mają uzasadnienie aksjologiczne normy systemu prawa"', 2) „przyznawanie znaczenia zasadniczego dyrektywom, które znajdują uzasadnienie aksjologiczne $\mathrm{w}$ wartościach uznawanych za najwyższe $\mathrm{w}$ proponowanym albo powszechnie przyjmowanym systemie preferencji”", 3) szczególny przedmiot ich regulacji, 4) okoliczność, że dana dyrektywa określa fundamenty jakiejś instytucji prawnej, 5) fakt, że dana dyrektywa stanowi rację dla szeregu innych norm. Jednocześnie podkreślił, że wskazane przez niego przesłanki nie stanowią katalogu zamkniętego'.

Po drugie, analizowane pojęcie jest łączone ,z wypracowanymi przez doktrynę uogólnieniami pewnych rozwiązań prawnych, a nawet wzorcami zachowania nieunormowanymi wyraźnie przez prawo, lecz uznanymi za wiążące"10. Tym samym pojęcie ,zasady prawa” obejmuje także zasady prawne formułowane w ramach działalności różnych organów orzekających, niezależnie bądź obok ustawodawstwa ${ }^{11}$.

Po trzecie, pojęcie ,zasady prawa” jest wykorzystywane „dla wskazania typu ukształtowania jakiejś instytucji prawnej (to znaczy funkcjonalnie powiązanego

\footnotetext{
${ }^{5}$ Z. Kmieciak, Ogólne zasady prawa i postępowania administracyjnego, Warszawa 2000, s. 35.

${ }^{6}$ Ibidem.

${ }^{7}$ K. Ziemski, op. cit., s. 76.

${ }^{8}$ Ibidem, s. 76-77.

${ }^{9}$ Ibidem, s. 77.

${ }^{10}$ Z. Kmieciak, op. cit., s. 35.

${ }^{11}$ Ibidem, s. 35-36.
} 
zespołu norm) odnoszącej się do określonej dziedziny spraw"12. Last but not least, zasady prawa czasami są

[...] utożsamiane z postulatami zawierającymi syntetyczne oceny i określającymi pożądany stan rzeczy. Opowiadając się za tym sposobem rozumienia rozpatrywanego pojęcia w sferze prawa administracyjnego, A. Jaroszyński zdecydowanie odrzucił możliwość wyodrębnienia zasad ogólnych tej gałęzi prawa jako norm prawnych lub norm-wniosków z innych norm ${ }^{13}$.

Jak widać, kwestia charakteru normatywnego zasad również należy do spornych. Kontrowersje dotyczą tego, czy są to wiążące normy prawa, czy tylko niewiążące postulaty ${ }^{14}$.

Słusznie zwraca uwagę M. Stahl, że możemy mówić o wielości zasad, zróżnicowaniu ich pojęcia oraz charakteru i podstaw prawnych, z których są one wywodzone lub z których wynikają ${ }^{15}$.

J. Łętowski stwierdził, że odnośnie do zagadnienia charakteru zasad wskazać można dwa stanowiska. „Pierwsze wyraża się w dążeniu do sprecyzowania »zasad prawa administracyjnego « [...] w sensie postulatywno-aksjologicznym (co do treści), a zatem w kierunku określenia naczelnych idei, ocen czy wartości, których realizacji prawo administracyjne (jako całość) miałoby służyć"16. Takie zasady miałyby być sformułowane przez teorię na podstawie norm prawa obowiązującego, najczęściej norm konstytucyjnych. Jednocześnie autor ten wskazuje, że w gruncie rzeczy ,nie tyle o postulatywno-aksjologiczne zasady chodzi, ale raczej o dyrektywalno-imperatywne; a więc jednak o normy (bez wchodzenia obecnie w problem ich charakteru), i to naczelne (szczególnie ważne) normy całej gałęzi prawa administracyjnego"17. Natomiast drugie stanowisko wyraża się w zaproponowaniu koncepcji uznania zasad ogólnych uregulowanych w kodeksie postępowania administracyjnego (k.p.a.) jako systemu zasad o charakterze normatywnym i przyjęciu ich jako przewodnich zasad sposobu działania polskiej administracji we wszystkich sferach jej działania. J. Łętowski podkreślił zarazem, że niewątpliwie ta idea była atrakcyjna teoretycznie, jednak nie można powołać się w niej na przekonywujące argumenty normatywne, ponieważ ich nie ma. Jego zdaniem kwestia pozycji zasad ogólnych wywodzonych z k.p.a. w polskim porządku prawnym jest ujmowana dość realistycznie, bowiem mają ograniczać się do roli, jaką wyznaczył im ustawodawca i zasadniczo odnosić się do sfery spraw poddanych regulacji proceduralno-kodeksowej. Zaznacza przy tym:

\footnotetext{
${ }^{12}$ Ibidem, s. 36.

${ }^{13}$ Ibidem.

${ }^{14}$ E. Olejniczak-Szałowska, op. cit., s. 112.

${ }^{15}$ M. Stahl, Wplyw zasad ogólnych ..., s. 240.

${ }^{16} \mathrm{~J}$. Łętowski, Prawo administracyjne. Zagadnienia podstawowe, Warszawa 1990, s. 231.

${ }^{17}$ Ibidem, s. 231-232.
} 
Ich praktyczny sens został jednak niezwykle podbudowany z momentem ustanowienia sądownictwa administracyjnego, NSA bowiem chętnie i w miarę często sięga do nich, a traktuje je dosyć rygorystycznie. Zdarza się zatem, iż decyzje administracyjne uchylane są właśnie z uwagi na sprzeczność z owymi zasadami, co nadaje im nie tylko ogólnokierunkowy, ale właśnie imperatywno-konkretny charakter. Tendencję tę należy uznać za słuszną i odpowiadającą potrzebom umacniania praworządności w administrowaniu ${ }^{18}$.

Z wywodów przeprowadzonych przez J. Łętowskiego można wysnuć jeszcze jeden wniosek - do „zasad prawa administracyjnego" należałoby zaliczyć nie tylko te, które możemy wywieść bezpośrednio tylko i wyłącznie z przepisów prawa administracyjnego, lecz i takie, które wynikają w równym stopniu z przepisów np. prawa cywilnego, prawa pracy czy z przepisów prawa administracyjnego. Trudno byłoby uznać, że np. zasada praworządności czy sprawiedliwości społecznej odnosi się tylko do administracji publicznej, należy ją bowiem odnieść do całości organizacji i funkcjonowania państwa. W związku z tym należałoby przyjąć, że są to zasady ogólne całego systemu prawa ${ }^{19}$. Stanowisko to należy zaaprobować jako trafne.

Z kolei E. Ura i E. Ura, powołując się na poglądy A. Jaroszyńskiego, wyrażają przekonanie, że nie można oddzielić zasad prawa i zasad działania organów administracji, ponieważ

[...] nie ma takich norm, które by miały zasadnicze znaczenie dla pozostałych rozwiązań prawnych. Inaczej sytuacja przedstawia się w poszczególnych działach tego prawa, np. w postępowaniu egzekucyjnym, prawie wywłaszczeniowym czy postępowaniu administracyjnym ogólnym. Dlatego trudno jest mówić o zasadach ogólnych prawa administracyjnego jako o normach prawnych, co nie oznacza, że taka norma w ogóle nie istnieje $\mathrm{e}^{20}$.

J. Starościak, rozważając problematykę zasad ogólnych prawa administracyjnego, zwrócił uwagę na brak kodyfikacji zasad ogólnych prawa administracyjnego, zaznaczając przy tym, że w tych działach prawa, które są skodyfikowane w całości lub w znacznej części, zasady te stanowią założenia wstępne dla rozwiązań szczegółowych. Wskazując na rolę zasad ogólnych prawa administracyjnego, uważa, że jest ona bliska tej, którą spełniają zasady współżycia społecznego w stosunkach cywilnoprawnych. Mają one stanowić niezbędne dopełnienie norm prawnych odnoszących się bezpośrednio do konkretnego przypadku ${ }^{21}$. Jego zdaniem:

${ }^{18}$ Ibidem, s. 232-233.

${ }^{19}$ Zob. ibidem, s. 231-232.

${ }^{20}$ E. Ura, E. Ura, op. cit., s. 61.

${ }^{21}$ J. Starościak, Źródła prawa administracyjnego. Zasady ogólne prawa administracyjnego, [w:] System prawa administracyjnego, red. J. Starościak, t. 1, Wrocław 1977, s. 152-153. 
Jako zasady nie są one konkretnymi przepisami prawa, lecz zgeneralizowaną treścią zespołu norm, choć poszczególne przepisy prawne mogą w sposób względnie ścisły reprezentować treść poszczególnych zasad ogólnych prawa administracyjnego. Zasada ogólna prawa administracyjnego, inaczej niż konkretny przepis prawny, rozciąga się natomiast na całość działania administracji bądź przynajmniej na stosunkowo szeroki i bliżej niesprecyzowany zakres działalności administracji. Sytuacja ta powoduje, iż niemożliwe jest wyliczenie zasad ogólnych prawa administracyjnego, podobnie zresztą jak niemożliwe jest zamknięcie listy zasad współżycia społecznego lub listy „,dobrych obyczajów" w prawie cywilnym²2.

Jednocześnie w tej sytuacji widzi siłę i związanie tych zasad z życiem. Autor ten przedstawił zasady ogólne prawa administracyjnego w dwóch ujęciach. Zgodnie $\mathrm{z}$ pierwszym ujęciem zasady te

[...] to wyraźnie ustawowo sformułowane zasady ogólne, wedle których działać mają organy administracyjne w zakresie unormowanym daną ustawą. Tak sformułowane zasady umieszczane są czy to we wstępach do ustaw, czy też we wstępnych artykułach aktów legislacyjnych. W obu wypadkach sens ich jednak jest podobny. Celem ich jest ułatwienie zrozumienia danej ustawy i ułatwienie interpretowania jej przepisów poprzez wyjaśnienie jej założeń. W tym ujęciu zasady ogólne są wyraźną normą prawną, choć normą szczególnego charakteru. Tak rozumiane i ujmowane zasady ogólne [...] są jako fragment ustawy normą obowiązującą tylko w zakresie stosowania samej ustawy ${ }^{23}$.

Drugie ujęcie sprowadza się do tego, że zasady ogólne prawa administracyjnego, dzięki ich „zasadniczości” i ogólnemu sformułowaniu, zawierają w sobie myśli, które są słuszne w szerszym zakresie i stają się przyjętą przez całą administrację linią działania, która wykracza poza prawnie ustalony zasięg działania ustawy. Zasady te są bowiem ,wykładnikiem sposobu działania całej administracji”24.

J. Starościak zauważa też, że - w związku z jednością całego systemu prawa - na wytworzenie zasad ogólnych działania administracji mają wpływ nie tylko przepisy prawa administracyjnego, lecz i innych działów prawa, a także sposób stosowania przepisów prawnych w praktyce. Ten wpływ przepisów innych - poza prawem administracyjnym - działów prawa jest tym silniejszy, im bardziej jest podkreślana jedność całego systemu prawa. Odnosząc się do kwestii charakteru zasad ogólnych prawa administracyjnego, z punktu widzenia prawnika, wyraża pogląd zbieżny ze stanowiskiem J. Wróblewskiego i uznaje, że „są to uogólnienia norm prawnych lub logiczne wnioski z treści tych norm"25. Jego zdaniem skoro zasady ogólne prawa administracyjnego to logiczne wnioski z norm prawnych, to zasady te są wnioskami interpretacyjnymi (zasada ogólna prawa administracyjnego nie mogłaby być sformułowana bez oparcia o konkretne normy czy bez

\footnotetext{
${ }^{22}$ Ibidem, s. 153.

${ }^{23}$ Ibidem, s. 154.

${ }^{24}$ Ibidem, s. 154-155.

${ }^{25}$ Ibidem, s. 157.
} 
powiązania z konkretnym przepisem prawa). Przyjmując taki charakter prawny zasad ogólnych prawa administracyjnego i zarazem przyjmując, że system prawa to normy prawne uporządkowane według ustalonych prawidłowości i powiązane łączącymi je założeniami, zasady te wchodziłyby w skład systemu prawa administracyjnego, a następnie w skład całego, jednolitego systemu prawa danego państwa. J. Starościak uznał za trafne stanowisko K. Opałka, że system prawa to „normy i zasady” obowiązującego prawa ${ }^{26}$. Cenna jest następująca konstatacja:

Zasady ogólne prawa administracyjnego są więc wnioskami ogólnymi z przepisów prawa i z ich stosowania, ale wiążąc się z innymi zasadami regulującymi zachowanie człowieka, stanowią tak ścisły stop tych różnych zasad, że stają się formacją przejściową od prawa ku normom etyki i moralności działania organów administracyjnych, że stają się płaszczyzną wiązania różnych przejawów świadomości społecznej z postanowieniami prawa. Stwierdzenie, iż zasady ogólne prawa administracyjnego to tylko logiczne wnioski z istniejącego systemu przepisów prawnych jest o tyle istotne, że rozwiązuje ono problem układu stosunków między tymi zasadami a konkretnie istniejącym przepisem prawnym. Zasada ogólna nie może bowiem mieć w tej sytuacji mocy „wyższej” niż przepis prawny, a tym bardziej mocy derogującej konkretny przepis prawny. Zasada ogólna wywodzi się bowiem z systemu obowiązujących przepisów. Ewentualna dysharmonia między treścią zasady a treścią konkretnego przepisu stanowiłaby więc układ: zasada - wyjątek, co oznacza nienaruszalność mocy konkretnego przepisu jako prawnie obowiązującego wyjątku od zasady ${ }^{27}$.

W doktrynie prawa administracyjnego są prezentowane rozmaite koncepcje zasad ogólnych. Uznaje się, że nie zawsze muszą one mieć postać norm prawa. Administracja publiczna jest nimi związana z różnych tytułów, nie tylko z uzasadnienia tetycznego ${ }^{28}$.

Przegląd stanowiska doktryny prawa administracyjnego na temat zasad prawa umieścił w swojej monografii K. Ziemski ${ }^{29}$. Jego zdaniem zasadą prawa jest „wypowiedź normatywna obowiązująca $\mathrm{z}$ uzasadnienia tetycznego albo stanowiąca bądź choćby mogąca stanowić wzorzec przyjęcia określonego rozwiązania prawnego, której przypisuje się nadrzędne w stosunku do innych dyrektyw znaczenie w oparciu o przyjęte przesłanki formalne bądź materialne"30.

W literaturze przedmiotu zwraca się uwagę również na stopień ogólności zasad, wskazując, że jest on różny - z zasad generalnych wynikają zasady bardziej szczegółowe ${ }^{31}$. Jako przykład można tutaj przywołać zasadę państwa prawnego. Zarazem w tym miejscu opracowania należy ograniczyć się do konstatacji, że „Szeroki zakres treściowy pojęcia demokratycznego państwa prawnego sprawia, że z zasady tej wyprowadza się w doktrynie i orzecznictwie wiele zasad szczegóło-

\footnotetext{
${ }^{26}$ Ibidem.

${ }^{27}$ Ibidem, s. $157-158$.

${ }^{28}$ Tak: E. Olejniczak-Szałowska, op. cit., s. 114.

${ }^{29}$ Zob. K. Ziemski, op. cit., s. 26-42.

${ }^{30}$ Ibidem, s. 77.

${ }^{31}$ E. Olejniczak-Szałowska, op. cit., s. 112.
} 
wych, określanych także jako standardy demokratycznego państwa prawnego"32. Z. Kmieciak zwraca uwagę na okoliczność, że pomimo braku definicji legalnej tego pojęcia, nadaje się mu wyraźną treść we współczesnej kulturze prawnej, ponieważ szczegółowe konsekwencje wynikające z tego pojęcia są określane przez doktrynę i organy orzekające (różnego rodzaju). Trafnie zauważa: „,...] zasada demokratycznego państwa prawnego pełni w istocie rolę klauzuli generalnej, której treść rekonstruowana jest na potrzeby konkretnego przypadku (rozstrzygnięcia prawnego)" 33 .

J. Starościak uznaje szczególną funkcję zasad ogólnych prawa administracyjnego w ramach gałęzi prawa administracyjnego. Ma być ona podobna do części ogólnej danej gałęzi prawa, która posiada swoją kodyfikację ${ }^{34}$. E. Ura i E. Ura wskazują ponadto takie funkcje analizowanych zasad ogólnych, jak: funkcja porządkująca ${ }^{35}$ (mająca odgrywać rolę podobną do tej, którą wskazał J. Starościak); realizowanie postulatu jednolitości działań administracji; zasady te mają być instrumentem wykorzystywanym jako środek mający zapewnić realizację określonej polityki administrowania (ograniczenie swobody działań administracji w ramach tzw. uznania administracyjnego); ujednolicenie wyników interpretacji przepisów prawa administracyjnego ${ }^{36}$. M. Stahl, dokonując analizy wybranych zasad ogólnych (które określiła jako mające charakter zasad prawa administracyjnego i administracji publicznej, zaliczając do nich: 1) zasadę decentralizacji, 2) zasadę subsydiarności, 3) zasadę sprawności [efektywności] działania administracji, rozumianą w aspekcie zdolności do wykonywania przypisanych tej administracji zadań, 4) zasadę samodzielności i autonomii organizacyjnej), stwierdziła:

Ich szczególna rola wiąże się z ich głębokim zakotwiczeniem w tradycji demokratycznej współczesnych państw i związanym z tym ich globalnym, uniwersalnym charakterem. [...] Wskazane zasady działają na różnych płaszczyznach, są ze sobą wzajemnie powiązane, przenikają się, a to wzmacnia ich znaczenie. Omawiane zasady mają charakter pewnych dyrektyw, standardów czy reguł optymalizacyjnych, są dynamiczne, rozwijają się, nabierają nowych znaczeń, z których wynikają nowe formy realizacji związanych z nimi celów. Są to zatem zasady otwarte, proces ich tworzenia nie może być uznany za zakończony. Cele, jakim mają służyć, to przede wszystkim dalsza demokratyzacja struktur władzy publicznej i procedur oraz dążenie do jak najefektywniejszej realizacji zadań publicznych ${ }^{37}$.

${ }^{32}$ M. Stahl, Zasada demokratycznego państwa prawnego, [w:] Prawo administracyjne. Pojęcia, instytucje, zasady..., s. 119.

${ }^{33}$ Z. Kmieciak, op. cit., s. 16.

${ }^{34}$ J. Starościak, op. cit., s. 163.

${ }^{35}$ Por. J. Szreniawski, Prawo administracyjne. Część ogólna, Lublin 1994, s. 103.

${ }^{36}$ E. Ura, E. Ura, op. cit., s. 63. Tak też: K. Ziemski, op. cit., s. 21-22.

${ }^{37}$ M. Stahl, Wpływ zasad ogólnych ..., s. 251. 
Jeśli chodzi o ośrodki formułowania zasad prawa administracyjnego/źródła zasad prawa administracyjnego, to wspomniano już, że w doktrynie prawa administracyjnego są prezentowane rozmaite koncepcje zasad ogólnych, uznając przy tym, że nie zawsze muszą one mieć postać norm prawa. Administracja publiczna jest nimi związana z różnych tytułów, nie tylko z uzasadnienia tetycznego. J. Starościak wskazał ponadto cztery inne źródła zasad prawa administracyjnego: 1) dyrektywy polityczne mające wpływ na tworzenie i stosowanie prawa, 2) praktyka administracyjna (praktyka wykonywania prawa), 3) orzecznictwo sądowe, 4) praca teoretyczna (poglądy teoretyków prawa zmierzające do ustalenia ogólnych zasad prawa ${ }^{38}$. Zasadnym jest, aby w tym kontekście wspomnieć o zasadach ogólnych postępowania administracyjnego, które znajdują się w k.p.a. Wskazano wcześniej na ich normatywny charakter. Źródłem tych zasad jest tekst ustawy, a więc widoczne jest tutaj wyraźnie uzasadnienie tetyczne ich obowiązywania. Wspomniano również o sporach dotyczących określenia zasięgu ich oddziaływania, dlatego warto w tym miejscu przytoczyć opinię B. Adamiak i J. Borkowskiego:

Są to zasady ogólne w tym sensie, że chodzi tutaj z reguły o przepisy wyjęte niejako przed nawias, a więc wspólne dla całości postępowania administracyjnego. Naczelny Sąd Administracyjny od początku swej działalności orzeczniczej niezgodność decyzji z zasadami ogólnymi traktował na równi z naruszeniem innych przepisów procesowych. Przepisy te uznane zostały za posiadające normatywny charakter, a nie za zbiór bezsankcyjnych deklaracji czy też skodyfikowanych doktrynalnych założeń postępowania administracyjnego ${ }^{39}$.

Za najbardziej kontrowersyjną uznaje się więc istotę zasad ogólnych prawa administracyjnego, sprowadzając ją do kwestii określenia normatywnego bądź nienormatywnego charakteru tych zasad ${ }^{40}$. Poglądy doktryny prawa administracyjnego są w tym zakresie zróżnicowane, co starano się pokrótce przedstawić powyżej.

Należy wyraźnie podkreślić, że nie ma jednego, uniwersalnego, absolutnego i wyłącznego, powszechnie akceptowanego katalogu zasad prawa administracyjnego. Proponowane klasyfikacje potwierdzają ich zróżnicowanie, stąd ich prezentacja ma charakter przykładowy.

K. Ziemski przedstawił jedną z najbardziej rozbudowanych klasyfikacji zasad prawa, zaznaczając, że typologia ta nie jest zupełna. Wyodrębnił on: 1) zasady w wersji opisowej, oceniającej oraz normatywnej, 2) zasady in abstracto oraz in

${ }^{38}$ J. Starościak, op. cit., s. 156.

${ }^{39}$ B. Adamiak, J. Borkowski, Postępowanie administracyjne a postępowanie cywilne - porównanie funkcji i zasad, [w:] Prawo. Administracja. Obywatele. Profesorowi Eugeniuszowi Smoktunowiczowi, red. B. Kudrycka, J. Mieszkowski, Białystok 1997, s. 37-38.

${ }^{40}$ Por. E. Ura, E. Ura, op. cit., s. 62-63; K. Ziemski, op. cit., s. 23-42 i n. 
concreto, 3) zasady systemu prawa oraz zasady części systemu, 4) zasady ogólne oraz zasady szczegółowe, 5) zasady naczelne i pomocnicze, 6) zasady tworzenia prawa oraz zasady stosowania prawa, 7) zasady ustrojowe, proceduralne i materialne, 8) zasady ustroju politycznego oraz zasady techniczne, 9) zasady ustanowione przez prawodawcę, zasady wypracowane przez doktrynę, zasady ukształtowane przez praktykę, 10) zasady wyrażające oceny instrumentalne, zasadnicze, globalne oraz preferencyjne, 11) zasady oceniające zachowania ludzkie oraz oceniające stan rzeczy, 12) zasady I i II stopnia, 13) zasady obowiązujące z uzasadnienia tetycznego oraz pozatetycznego, 14) zasady proste i zasady złożone, 15) zasady chroniące dobro jednostki, zasady chroniące dobra ogólnospołeczne oraz zasady chroniące oba rodzaje dóbr, 16) zasady działań wewnętrznych oraz zasady działań zewnętrznych ${ }^{41}$.

Autor ten stwierdza, że podział zasad na abstrakcyjne i konkretne jest doniosły zarówno dla nauki, jak i praktyki stosowania prawa administracyjnego.

Ukazuje on bowiem w sposób jasny, że działania administracji regulowane są całym szeregiem dyrektyw zaliczanych do zasadniczych, które jednak wiążą administrację z różnego tytułu. Uświadomienie, że nie wszystko co ma moc obowiązującą wiąże z uzasadnienia tetycznego, ma pierwszorzędne znaczenie. Dotyczy to szczególnie sytuacji, kiedy to dochodzi do kolizji między nimi. Zasady abstrakcyjne w żadnym przypadku nie mogą stanowić uzasadnienia dla prób obchodzenia czy wręcz łamania prawa ${ }^{42}$.

Jego zdaniem zasady in concreto są obowiązującymi normami prawa, natomiast zasady in abstracto są to

[...] formułowane pod adresem prawodawcy postulaty oraz wypowiedzi dyrektywalne, które co prawda nie zostały sformułowane jako propozycja określonej regulacji prawnej, jednakże z uwagi na ich charakter mogą taką funkcję pełnić. Zasady abstrakcyjne to niekoniecznie ogólne wskazanie możliwego kierunku rozwiązania w ustawie jakiegoś zagadnienia. Może to być także szczegółowy postulat przyjęcia określonego rozwiązania prawnego ${ }^{43}$.

J. Łętowski wyróżnił zasady organizacji administracji, wśród których jako podstawową wskazał zasadę kierownictwa, oraz zasady funkcjonowania administracji, do których zaliczył: 1) zasadę praworządności, 2) zasadę efektywności, 3) zasadę jawności, 4) zasadę zaufania, 5) zasadę odpowiedzialności. Ponadto autor ten jako zasady ogólne postępowania administracyjnego wymienia: 1) zasadę praworządności, 2) zasadę prawdy obiektywnej, 3) zasadę ochrony interesu społecznego i słusznego interesu stron, 4) zasadę udziału stron w postępowaniu, 5) zasadę pogłębiania zaufania obywateli do organów państwa, 6) zasadę szyb-

\footnotetext{
${ }^{41}$ K. Ziemski, op. cit., s. 57-69.

${ }^{42}$ Ibidem, s. 119.

${ }^{43}$ Ibidem, s. 78.
} 
kości i prostoty, 7) zasadę pisemności, 8) zasadę trwałości decyzji, którą należy łączyć z zasadą dwuinstancyjności postępowania ${ }^{44}$.

E. Ura i E. Ura odnoszą się do podstawowych zasad prawa administracyjnego i administracji, kwalifikując do nich: 1) zasadę praworządności, 2) zasadę demokratyzmu, 3) zasadę udziału obywateli w administrowaniu, 4) zasady współżycia społecznego, 5) zasadę jawności działań administracji, 6) zasadę kompetencyjności, 7) zasadę efektywności oraz 8) inne zasady występujące w prawie administracyjnym i działaniach administracji (zasada prawdy obiektywnej, zasada ochrony zaufania obywateli, zasada sprawiedliwości społecznej, zasada ochrony interesu społecznego i indywidualnego, zasada współdziałania, zasada skuteczności). Akcentują oni, iż - inaczej niż konkretny przepis prawny - zasady prawa administracyjnego rozciągają się na całość działania administracji albo na względnie szeroki zakres tej działalności, co powoduje, że katalog zasad ogólnych prawa administracyjnego nie jest zamknięty ${ }^{45}$.

Z. Kmieciak eksponuje natomiast klasyfikację zasad prawa administracyjnego (materialnego i procesowego) zaproponowaną przez komisję ekspertów państw członkowskich Rady Europy. Do zasad prawa materialnego należą zatem: 1) zasada praworządności, 2) zasada równości wobec prawa, 3) zasada zgodności działania z celem ustawowym, 4) zasada proporcjonalności, 5) zasada obiektywizmu i bezstronności, 6) zasada ochrony zaufania i praw słusznie nabytych, 7) zasada otwartości administracji. Do zasad proceduralnych zaliczono: 1) zasadę dostępu do usług publicznych (urzędu administracyjnego), 2) prawo do wysłuchania, 3) prawo do wsparcia i reprezentacji w postępowaniu, 4) prawo do rozpatrzenia sprawy w rozsądnym terminie, 5) prawo do powiadomienia o rozstrzygnięciu, poznania jego motywów oraz pouczenia o środkach zaskarżenia, 6) zasadę zapewnienia wykonania podjętego aktu w rozsądnym terminie ${ }^{46}$.

Interesującą, oryginalną typologię zasad prawa administracyjnego zaproponował Z. Cieślak. Sformułował on tezę, że

[...] zasady prawa administracyjnego nie są normami prawa administracyjnego, przybierają postać swoistych dyrektyw prakseologicznych. Swoistość owych dyrektyw prakseologicznych polega na tym, iż - po pierwsze - ze względu na jedność systemu prawa dotyczą one jednocześnie stanowienia i stosowania prawa (są więc dyrektywami stanowienia i stosowania prawa), po drugie - formułowane są na podstawie analizy treści obowiązującego prawa, po trzecie - są pod względem treści związane (jest to kolejna zasadnicza cecha wynikająca z jedności systemu prawa) i po czwarte - niektóre $\mathrm{z}$ tych dyrektyw ustawodawca deklaruje wprost w przepisach prawa (np. zasada dwuinstancyjności postępowania - art. 15 k.p.a. $)^{47}$.

${ }^{44}$ J. Łętowski, op. cit., s. 70-76, 136-153, 233-234.

${ }^{45}$ E. Ura, E. Ura, op. cit., s. 60, 64-73.

${ }^{46}$ Z. Kmieciak, op. cit., s. 43-44.

${ }^{47}$ Z. Cieślak, Zasady prawa administracyjnego, [w:] Z. Niewiadomski (red.), Z. Cieślak, I. Lipowicz, G. Szpor, Prawo administracyjne, Warszawa 2007, s. 63. 
Jako kluczowe zasady stanowienia i stosowania prawa autor ten uznaje zasadę prawnej legitymizacji działania organów administracji publicznej (ma ona mieć uniwersalny charakter, ponieważ stanowi prakseologiczny i prawny wymiar podstawowych, konstytucyjnych założeń demokratycznego państwa prawnego, ponadto ma całkowicie przenikać system obowiązującego prawa) oraz zasadę realizacji dobra wspólnego (ma ona mieć partykularny charakter, gdyż odnosi się przede wszystkim do prawa administracyjnego, identyfikując je w sposób szczególny) ${ }^{48}$. W ramach tych dwóch zasad Z. Cieślak wyszczególnił katalog zasad szczegółowych, do których - jego zdaniem - należą: 1) zasada optymalnej pojemności kompetencyjnej organów, 2) zasada rozdzielności kompetencji organów, 3) zasada oznaczenia form organizacyjnego oddziaływania, 4) zasada określenia skutków organizacyjnych administrowania, 5) zasada prawdy materialnej, 6) zasada dwuinstancyjności postępowania, 7) zasada domniemania prawidłowości aktów administracyjnych, 8) zasada trwałości aktów administracyjnych, 9) zasada identyfikacji dobra wspólnego, 10) zasada ważenia interesów państwa, wspólnot i obywateli, 11) zasada oznaczenia form materialnoprawnego oddziaływania, 12) zasada określenia skutków materialnoprawnego oddziaływania ${ }^{49}$.

Podsumowując, należy zauważyć, że pojęcie „zasady prawa administracyjnego" (w różnych ujęciach tego sformułowania) na gruncie nauki prawa administracyjnego nie różni się istotnie od pojmowania tych zasad w teorii prawa. K. Ziemski wyraził nawet niegdyś opinię, że „Konstruowanie pojęcia zasad prawa, specjalnie na użytek prawa i nauki prawa administracyjnego, jest nieuzasadnione. Jest to pojęcie na tyle ogólne, że zaliczyć je należy do podstawowych dla całego prawoznawstwa, a jego konstrukcja winna być wspólna dla całego systemu prawa" ${ }^{50}$. Należy się z tą opinią zgodzić, tak jak zasadną jest aprobata dla stwierdzenia, że choć

[...] konstruowanie pojęcia zasad prawa specjalnie na użytek prawa administracyjnego jest nieuzasadnione, to jednak swoistości tego działu prawa znajdą odzwierciedlenie w katalogu zasad charakterystycznych dla prawa administracyjnego. Obok zasad systemu prawa w prawie administracyjnym wyróżnić można zasady albo niewystępujące w innych działach prawa, albo też mające w ich obrębie nieco odmienną treśćc ${ }^{1}$.

W kontekście analizowanej w ramach niniejszego opracowania problematyki warto wspomnieć pokrótce o idei uchwalenia zasad ogólnych prawa administracyjnego, które miały mieć formę skodyfikowanych zasad tej gałęzi prawa, stanowiąc przepisy, które miały być „wyjęte przed nawias” wszelkiej działalności administracji publicznej w państwie. Jak zauważa E. Olejniczak-Szałowska,

\footnotetext{
${ }^{48}$ Ibidem.

${ }^{49}$ Ibidem.

${ }^{50} \mathrm{~K}$. Ziemski, op. cit., s. 111.

${ }^{51}$ Ibidem.
} 
koncepcja stworzenia części ogólnej prawa administracyjnego pojawiała się w piśmiennictwie od wielu lat (pisał o niej m.in. J.S. Langrod, J. Starościak, J. Borkowski, J. Świątkiewicz, E. Smoktunowicz, Z. Leoński, A. Wasilewski, Z. Kmieciak).

W toku dyskusji nad projektami ustawy - Przepisy ogólne prawa administracyjnego wyłoniły się trzy stanowiska: popierające projekty, przeciwne i kompromisowe, lecz sceptyczne. Dyskutowano, czy należy ograniczyć się do zamieszczenia w przyszłej ustawie jedynie zasad ogólnych prawa administracyjnego, czy też rozszerzyć zakres regulacji także na postanowienia dotyczące tworzenia i stosowania prawa administracyjnego. W kolejnych projektach ustawy - Przepisy ogólne prawa administracyjnego eksponowano normatywny charakter postanowieńn ${ }^{52}$.

Obecnie idea ta spełzła na niczym, a winą za ten stan rzeczy należy obarczyć samo prawo administracyjne, które jest bardzo rozległe, jeśli chodzi o przedmiot regulacji, zmienne, płynne, związane z panującą doktryną polityczno-ustrojową, wewnętrznie niespójne - przedmiotem regulacji administracyjnoprawnej są bowiem zagadnienia zarazem zróżnicowane i złożone, które ulegają nieraz tak szybkim zmianom, że uważa się wręcz, iż „nie jest możliwe sformułowanie zasad prawnych równocześnie na tyle ogólnych i trwałych zarazem, które mogłyby być skodyfikowane" ${ }^{53}$ (oczywiście - poza procedurą).

\section{ZASADA PAŃSTWA PRAWNEGO NA GRUNCIE PRAWA ADMINISTRACYJNEGO}

Przedstawione wyżej rozważania dotyczące zasad prawa administracyjnego, ujmowanych w kontekście zasad systemowych, rodzi pytanie o to, którą z zasad należałoby wyszczególnić. Odpowiedzi udzieliliśmy przy samym sformułowaniu tematu artykułu. Wskazanie zasady państwa prawnego ma swoje szczególne znaczenie z kilku względów: po pierwsze - wiąże się z koniecznością odpowiedzi na pytanie o pojęcie i istotę prawa; po drugie - jest to zasada, która znajduje swoje konstytucyjne umocowanie; po trzecie - jej treść powinna znaleźć umocowanie w aksjologicznych podstawach ładu prawnego w Rzeczypospolitej; po czwarte - jest to zasada, którą można rozpatrywać w kontekście nie tylko prawa administracyjnego, ale także innych dziedzin i gałęzi prawa (ma przez to wymiar ogólnosystemowy, chociaż na gruncie prawa administracyjnego spełnia ona szczególną rolę).

${ }^{52}$ E. Olejniczak-Szałowska, op. cit., s. 113-114.

${ }^{53}$ J. Boć, Cechy źródet prawa administracyjnego, [w:] Prawo administracyjne, red. J. Boć, Wrocław 2007, s. 59. Zob. J.S. Święcki, Przepisy ogólne prawa administracyjnego jako problem badawczy $w$ teorii prawa administracyjnego, [w:] Nowe problemy badawcze $w$ teorii prawa administracyjnego, red. J. Boć, A. Chajbowicz, Wrocław 2009, s. 465-476. 
Wydawać by się mogło, że pytanie dziś o pojęcie i istotę prawa nie ma żadnego głębszego uzasadnienia. Przecież sformułowano już dziesiątki różnych definicji, napisano setki rozpraw. Tyle tylko, że w większości z nich ujmuje się prawo w kategoriach statycznych. Do tego przecież w efekcie prowadziły koncepcje pozytywistyczne i normatywistyczne. Problem tkwi w tym, na co zasadnie zwracał uwagę M.A. Krąpiec:

[...] że pozytywiści biorą zewnętrzne przejawy prawa, np. fakt ustanowienia przez parlament, za prawo. Ale to ustanowienie przecież nie stanowi istoty prawa i nie daje mocy prawnej. Moc prawa płynie z dobra, które dla prawa jest celem, racją obowiązywania i do realizowania, którego to prawo zobowiązuje w takich okolicznościach [...]. Prawo nic nie znaczy, jeśli nie przejdzie przez filtr sumienia. Prawo wtedy rzeczywiście jest skuteczne, gdy staje się sądem praktycznym wybranym dobrowolnie przez człowieka ${ }^{54}$.

Niewątpliwie z takim podejściem koresponduje stanowisko znakomitego polskiego administratywisty F. Longchampsa, który stwierdza:

Oczywiście w kulturze prawnej struktura normatywna jest szczególnie silnie rozwiniętym składnikiem, ale tylko składnikiem. Bo w tak pojętej kulturze prawnej normy prawne ukazują się jako osadzone w swoim społeczeństwie i czasie, i tylko tak się ukazują. Jedną więc całością objęte są i normy prawne, i ich obowiązywanie (czyli pewien szczególny sposób ich utrzymywania się w życiu społeczeństwa, ich trwania), i przyczyny tego obowiązywania, i jego skutki ${ }^{55}$.

Takie podejście w jakimś sensie przywraca starorzymską celsusowską tezę, że prawo jest ordo boni ac ratio (,porządkiem dobra i rozumnej słuszności”).

Można byłoby to ujęcie rozszerzyć i przyjąć, że prawo jest sztuką tego, co dobre, słuszne, roztropne, racjonalne i sprawiedliwe. Oznacza to potrzebę odejścia od skrajnie pozytywistycznych wizji prawa i państwa prawnego. „Pozytywista, który widzi jedynie ustawy i zamyka się wobec wszelkich pozaustawowych momentów prawa - podkreślał A. Kaufmann - jest z tego powodu [...] w zasadzie bezsilny wobec każdego spaczenia prawa przez siłę polityczną" ${ }^{56}$. Takie podejście musi zakładać tezę, że idea państwa prawnego nie może opierać się tylko na jakimś konkretnym przepisie zawartym w akcie normatywnym (akcie prawa pozytywnego) i literalnym brzmieniu tego przepisu. W większości systemów prawnych, ani w konstytucjach, ani w ustawach, nie dokonuje się rozdzielenia pojęcia przepisów prawnych i norm prawnych. Jest to konsekwencją przyjęcia założenia, że oczywista jest ich nietożsamość albo też biegunowo odmienne stanowisko zakładające taką tożsamość.

${ }^{54}$ M.A. Krąpiec, Suwrenność, by ocalić, Torun 1997, s. 8.

${ }^{55}$ F. Longchamps, Z problemów poznania prawa, Wrocław 1968, s. 32-33.

${ }^{56}$ A. Kaufmann, Rechtsphilosophie, Rechtstheorie, Rechtsdogmatik, [w:] Einfuhrung in Rechtsphilosophie und Rechtstheorie der Gegenwort, Heidelberg 1989, s. 17. 
Pewien wyjątek tym zakresie stanowi art. 20 ust. 3 Konstytucji Republiki Federalnej Niemiec z 23 maja 1949 r., gdzie zostało wyrażone jasne stanowisko ustrojodawcy niemieckiego, który w art. 20 ust. 3 przyjmuje bardzo wymowną w tej materii tezę, że ,wymiar sprawiedliwości sprawowany jest w oparciu o prawo i ustawę". W podobnym kierunku idą czasem ważne regulacje ustawowe w niektórych krajach europejskich, jednakże nie na gruncie prawa administracyjnego, a cywilnego ${ }^{57}$.

Mając na uwadze taki stan rzeczy, przy personalistycznym podejściu do prawa i zasady państwa prawnego, należy przyjąć, że norma prawna ma w rzeczywistości jakby dwie strony, tj. esencjalną i egzystencjalną. Strona esencjalna normy prawnej wiąże ją z konkretnym przepisem prawnym albo z przepisami prawa pozytywnego. Często przyjmuje się, że strona esencjalna jest prawem w możności. Wskazuje ona przez to na kierunki działania organu stosującego prawa w procesie subsumcji. Owa „możność” w działaniu organu stosującego prawo z jednej strony wiąże organ stosujący prawo z treścią prawa pozytywnego, z drugiej zaś nakłada na niego obowiązek poszukiwania optymalnej formuły treści normy prawnej. Jeżeli w konkretnym przepisie prawa znajdują się pojęcia o dużym stopniu niedookreśloności, wzrasta „możność” poszukiwania przez stosujący prawo organ państwa (np. organ administracji publicznej) optymalnej formuły prawa (normy prawnej). Jednocześnie zwiększa się odpowiedzialność takiego organu za zagospodarowanie sfery wolności, która wynika z luzów normatywnych. Wolność tego rodzaju zawsze jest czymś zadanym, a nie nadanym. Można nawet stwierdzić, że rodzi ona swoiste obowiązki po stronie organu stosującego prawo.

Druga strona normy prawnej, którą określiłem mianem egzystencjalnej, wiąże się z tzw. życiem prawnym przepisu prawnego. Każdy przepis prawny czy akt normatywny jest niejako zanurzony w rzeczywistości, w której ma funkcjonować. Taki stan rzeczy oznacza nie tylko możność, ale i konieczność uwzględnienia w procesie wykładni m.in.

a) aksjologicznych podstaw obowiązującego systemu prawa, naturalnego porządku rzeczy (prawa naturalnego), zasad sprawiedliwości, prawości woli, świadomości prawnej itd., b) okoliczności faktycznych, do których prawo odnosi się, c) norm, reguł i zasad pozasystemowych będących następstwem rozwoju cywilizacyjnego (normy i normatywy techniczne, normy wiedzy,

57 „Artykuł 4 szwajcarskiego kodeksu cywilnego z 1907 r. nakłada na sędziów obowiązek uwzględniania przy wydawaniu orzeczeń zasad prawa i sprawiedliwości. Sędzia francuski czy belgijski, gdy prawo milczy, jest niejasne lub niewystarczające, ma prawo odwołać się do zasad słuszności (art. 2 kodeksu cywilnego)". Zob. M. Zdyb, Państwo prawa w perspektywie zaszłości historycznych oraz dokonujących się zmian, [w:] Współczesne problemy prawa publicznego, red. S. Fundowicz, Lublin 1999, s. 17-49; idem, Drogi i bezdroża państwa prawnego, [w:] Konstytucja, ustrój, system finansowy państwa. Księga pamiatkowa ku czci Prof. Natalii Gajl, Warszawa 1999, s. $197-235$. 
zasady prakseologiczne itd.), d) praktyki stosowania prawa (m.in. orzecznictwa), e) poglądów doktryny itd. ${ }^{58}$

Przeprowadzone wyżej wywody wyraźnie wskazują na to, że faktycznie w kształtowaniu treści normy prawnej i zasady państwa prawnego ważną rolę spełnia nie tylko prawodawca, ale także organ stosujący prawo. Trybunał Konstytucyjny Rzeczypospolitej Polskiej wielokrotnie w swoich wyrokach dawał wyraz temu, że podstawą do oceny zgodności z Konstytucją RP jest nie tylko literalne brzmienie kwestionowanego przepisu prawnego, ale i to, jakie treści - przede wszystkim sądy - tym przepisom przypisują. Jeżeli ukształtowała się pewna linia orzecznicza dotycząca wykładni przepisów prawa i ta linia prowadziła tak rozumiane przepisy prawne do niezgodności z Konstytucją, to mogło i kilkakrotnie stanowiło to podstawę do orzeczenia ich niezgodności z Konstytucją, nawet jeżeli istniała możliwość interpretacji niebudzącej konstytucyjnych wątpliwości. Jako wzorzec, czy też jeden z wzorców, kontroli wskazywano wtedy art. 2 Konstytucji, w świetle którego „Rzeczpospolita Polska jest demokratycznym państwem prawa urzeczywistniającym zasady sprawiedliwości społecznej”. W moim przekonaniu takie stanowisko można było uznać jako w pełni uzasadnione. Na okoliczność, że o treści normy prawnej w konkretnym układzie odniesienia decyduje nie tylko prawodawca (organ kreujący przepis prawa) czy konkretne organy stosujące prawo, że jest to złożony i skomplikowany proces, zwracało uwagę szereg wybitnych prawników, w tym m.in. G. Radbruch ${ }^{59}$, K. Engisch ${ }^{60}$, H.-G. Gadamer ${ }^{61}$ itd. Dziś nie budzi wątpliwości okoliczność, że zasady demokratycznego państwa prawnego nie można sprowadzić tylko do zasady praworządności, chociaż jest ona ważnym elementem ładu publicznego.

Zasada państwa prawnego do polskiego porządku prawnego została wprowadzona w grudniu 1989 r. i od razu otrzymała konstytucyjne umocowanie, ponieważ art. 1, jeszcze mocno przekształconej konstytucji stalinowskiej, otrzymał brzmienie, wedle którego „Rzeczpospolita Polska jest demokratycznym państwem prawnym urzeczywistniającym zasady sprawiedliwości społecznej”. Utrzymany został on w mocy przez ustawę konstytucyjną z dnia 17 października $1992 \mathrm{r}$. o wzajemnych stosunkach między władzą ustawodawczą i wykonawczą Rzeczypospolitej Polskiej oraz o samorządzie terytorialnym ${ }^{62}$. Aktualnie jest ona wyartykułowana w art. 2 Konstytucji Rzeczypospolitej Polskiej z dnia 2 kwietnia 1997 r. Do 1997 r. stanowił on kluczową podstawę do kształtowania w orzecznictwie

\footnotetext{
${ }^{58}$ Patrz szerzej: idem, Prawny interes jednostki w sferze materialnego prawa administracyjnego. Studium teoretyczno-prawne, Lublin 1991.

${ }^{59}$ G. Radbruch, Die Natura der Sache als juristische Denkform, Dormstadt 1960.

${ }^{60} \mathrm{~K}$. Engisch, Einfuhrung in das juristische Denken, Stuttgart 1959.

${ }^{61}$ H.-G. Gadamer, Wahrheit und Methode, Tubingen 1975.

${ }^{62}$ Dz.U., nr 84, poz. 426 z późn. zm.
} 
Trybunału Konstytucyjnego podstawowych standardów ustrojowych Rzeczypospolitej Polskiej. Większość z nich została wpisana potem do Konstytucji RP z 1997 r. Mimo to jego utrzymanie w Konstytucji jest ze wszech miar uzasadnione. Za takim stanowiskiem przemawia okoliczność, że takie przepisy Konstytucji, jak art. 1 („Rzeczpospolita Polska jest dobrem wszystkich obywateli”), art. 30: „Przyrodzona i niezbywalna godność człowieka stanowi źródło wolności i praw człowieka i obywatela. Jest ona nienaruszalna, a jej poszanowanie i ochrona jest obowiązkiem władz publicznych", a także cytowany już art. 2 Konstytucji w aktualnym brzmieniu („Rzeczpospolita Polska jest demokratycznym państwem prawnym urzeczywistniającym zasady sprawiedliwości społecznej"), stanowią nadal podstawę do identyfikacji wartości, które leżą lub powinny leżeć u podstaw ładu publicznego w Rzeczypospolitej Polskiej.

Mimo że aktualnie obowiązująca Konstytucja Rzeczypospolitej Polskiej dokonała identyfikacji i wyartykułowania wielu wcześniej niewyrażanych wprost zasad i wartości kształtujących podstawy ładu publicznego w państwie, zasada państwa prawnego jest nadal ważnym elementem w budowaniu takiego ładu, i to z kilku względów. Po pierwsze - zwraca ona pośrednio lub bezpośrednio uwagę na potrzebę współistnienia dobra wspólnego oraz godności człowieka. Dotyczący dobra wspólnego art. 1 Konstytucji RP oraz jej art. 30, wskazujący na to, że godność człowieka jest źródłem wszelkich praw i wolności, mają niewątpliwie odniesienia transcendentne. Odwołują się w sposób wprawdzie nietożsamy, w większym lub mniejszym zakresie, do wartości wykraczających poza prawo pozytywne.

Godność - jak słusznie w tym kontekście zauważa D. Dudek - mająca istotne znaczenie i implikacje, nie jest bowiem instytucją prawną, przez prawo wykreowaną i ściśle unormowaną [...]. Stanowi ona zjawisko pierwotne i niezależne wobec prawa, związane z egzystencją człowieka, możliwe do rekonstrukcji definicji raczej filozoficznej (antropologicznej i etycznej) czy filozoficznoprawnej niż ściśle dogmatyczno-prawnej ${ }^{63}$.

Można powiedzieć, mając na uwadze te prawa, które czerpią swoją moc z art. 30 Konstytucji RP i w Konstytucji zostały zapisane, że także posiadają one ponadpozytywne uzasadnienie, które wynika ze swoistego promieniowania godności człowieka na te prawa. W zakresie dotyczącym godności człowieka, ze względu na pewne podobieństwo wynikające z Konstytucji Republiki Federalnej Niemiec, przydatne mogą być poglądy doktryny niemieckiej. Dogłębną ich analizę przeprowadził F.J. Mazurek ${ }^{64}$.

${ }^{63}$ Zasady ustroju III Rzeczypospolitej Polskiej, red. D. Dudek, Warszawa 2009, s. 43-44.

${ }^{64}$ Podkreśla on: „Nie zadowolono się jedynie formalnym pojęciem prawa. Odstąpiono od pozytywizmu prawnego, ale nie w tym sensie, że zrezygnowano z umieszczenia praw człowieka w prawie stanowionym, lecz w tym sensie, że oparte są one na najwyższej wartości - godności człowieka - a nie na woli prawodawcy. Prawo stanowione sprzeczne z tą wartością jest nie-pra- 
Bardzo bogatą literaturę posiada także problematyka dobra wspólnego. Mając na uwadze godność człowieka oraz dobro wspólne, rzec można, że wiele rozwiązań konstytucyjnych stanowi pewną formę rozpisania na czynniki pierwsze relacji dobro wspólne - godność człowieka. Obie te wartości nie pozostają (nie muszą pozostawać) w opozycji do siebie, ponieważ wzajemnie się dopełniają. Zasada państwa prawnego, o ile jest właściwie pojmowana, powinna tworzyć swoisty pomost pomiędzy nimi.

Po drugie - z tej racji, że wiele dzisiaj zapisanych w Konstytucji RP praw i wolności, wartości i zasad, było wyprowadzanych z pomieszczonej wcześniej zasady państwa prawnego, zasadę tę można traktować jako swoisty łącznik pomiędzy innymi zasadami ładu publicznego, który można ujmować także w aksjologicznej perspektywie. Okoliczność, że zasada demokratycznego państwa prawnego była swoistym źródłem do ich identyfikacji niewątpliwie ułatwia formułowanie wielu innych zasad i określanie ich treści. Bogate orzecznictwo Trybunału Konstytucyjnego, poglądy doktryny itd. tworzą dodatkowe standardy dla kształtowania optymalnej formuły państwa prawnego.

Po trzecie - zasada ta, obok zasady dobra wspólnego i godności człowieka, stanowi swoistą aksjologiczną podstawę dla właściwego pojmowania zasad ogólnych kodeksu postępowania administracyjnego, które mają wymiar nie tylko proceduralny, ale też materialnoprawny i ustrojowy. W art. 6-16 kodeksu postępowania administracyjnego ustawodawca sformułował podstawowe zasady, które stanowią punkt wyjścia dla kształtowania się zasady państwa prawnego i jego aksjologicznych podstaw na gruncie prawa administracyjnego w płaszczyźnie materialnoprawnej, proceduralnej i ustrojowej. Chodzi tu m.in. o takie zasady, jak: a) zasada praworządności, b) zasada prawdy obiektywnej, c) zasada uwzględniania interesu publicznego i słusznego interesu obywateli, d) zasada pogłębiania zaufania obywateli do organów państwa i pogłębiania kultury prawnej, e) zasada udzielania pomocy prawnej, f) zasada udziału stron w postępowaniu, g) zasada

wem [Unrecht] - jest prawem niesprawiedliwym. Odniesienie prawa do człowieka znaczy, że jest ono wiążącą wskazówką działania wobec człowieka i człowiek jest miarą dla działań publicznych i prywatnych. Nie jest tą miarą ani gospodarka, ani ideologia, ani też państwo. Dlatego w centrum konstytucji umieszczono nienaruszalną godność człowieka. Prawo zapisane w konstytucji nie może być traktowane jako wiążące tylko dlatego, że jest ustanowione przez wolę sprawujących władzę w państwie. Konstytucja nie neguje uprawnień władzy państwowej stanowienia prawa, jego znaczenia i siły wiążącej, ale zawsze w granicach najwyższej zasady godności człowieka, zasady społecznego państwa prawa i nienaruszalnych praw człowieka. Podstawowe prawa człowieka są w konstytucji uznawane jako przedpaństwowe i ponadpozytywne. Nie państwo określa, czy i jak człowiek powinien korzystać ze swych praw, lecz one określają co państwo może czynić - chronić je a w szczególności czego nie może czynić w tym zakresie - nie może naruszać czy zawieszać korzystania z nich. Państwo może je ograniczać, ale tylko w przypadkach ściśle określonych przez konstytucję, to jest jeśli jednostka, korzystając z tych praw, narusza prawa człowieka innych, wykracza przeciwko konstytucyjnemu porządkowi i prawu moralnemu”. Zob. F.J. Mazurek, Godność osoby ludzkiej podstawa praw człowieka, Lublin 2001, s. 157-158. 
przekonywania i troski o dobro wspólne, h) zasada szybkości i prostoty, i) zasada nakłaniania do ugody stron o spornych interesach, j) zasada pisemności, k) zasada dwuinstancyjności, 1) zasada trwałości decyzji itd.

Po czwarte - może ona dziś dawać podstawę do kreowania prawa do dobrej administracji. Prawo takie nie zostało wprost wyrażone w Konstytucji RP ani w innym akcie normatywnym. Wydaje się jednak, że fakt czy też potrzeba jego identyfikacji nie budzą zastrzeżeń. Ważne znaczenie w tym zakresie ma kształtowana praktyka orzecznicza, zwłaszcza Trybunału Konstytucyjnego oraz sądownictwa administracyjnego (najpierw Naczelnego Sądu Administracyjnego, a aktualnie wojewódzkich sądów administracyjnych i Naczelnego Sądu Administracyjnego) ${ }^{65}$. Jeszcze w początkach funkcjonowania Naczelnego Sądu Administracyjnego wydał on szereg orzeczeń dotyczących kształtowania i porządkowania źródeł prawa powszechnie obowiązującego, stanowiącego podstawę do wydawania decyzji administracyjnych. Już w jednym z początkowych orzeczeń przyjął on, że:

1. Tak zwana samoistna uchwała Rady Ministrów, tzn. uchwała wydana bez upoważnienia zawartego w ustawie lub dekrecie z mocą ustawy, nie może stanowić podstawy prawnej do wydania przez organ administracji państwowej decyzji nakładającej określone obowiązki na spółdzielnie, nie może również stanowić podstawy prawnej do wydania przez organ administracji państwowej decyzji nakładającej obowiązki na osoby fizyczne oraz organizacje zawodowe, a także inne osoby prawne i organizacje niebędące państwowymi jednostkami organizacyjnymi. 2. Podstawą prawną do wydania przez organ administracji państwowej decyzji nakładającej określone obowiązki na osoby fizyczne lub prawne i organizacje niebędące państwowymi jednostkami organizacyjnymi może być - z uwagi na fakt, że dotyczy to sfery praw i wolności obywatelskich - jedynie przepis prawa powszechnie obowiązującego, a więc aktu ustawodawczego [...] albo aktu wykonawczego wydanego na podstawie i w granicach wyraźnego upoważnienia zawartego $\mathrm{w}$ akcie wykonawczym ${ }^{66}$.

Takie stanowisko NSA prezentował również w wyroku z dnia 20 lipca 1981 r., gdzie przyjął, że:

Akty prawodawcze niemające mocy powszechnie obowiązującej, jakimi są m.in. uchwały Rady Ministrów wydane bez upoważnienia ustawy (tzw. uchwały samoistne), nie mogą stanowić podstawy prawnej decyzji administracyjnych. O obowiązkach obywateli i ich organizacji mogą decydować wyłącznie przepisy ustawowe [...]. Powyższa zasada ma odpowiednie zastosowanie do decyzji administracyjnych przyznających uprawnienia, albowiem uprawnienie ma charakter relatywny i wtórny w tym znaczeniu, jest pochodną uprzedniego poddania danej dziedziny życia reglamentacji prawnej ${ }^{67}$.

${ }^{65}$ Zob. szerzej: M. Zdyb, Ksztaltowanie standardów demokratycznego państwa prawnego w orzecznictwie sądowo-administracyjnym, [w:] Księga jubileuszowa z okazji 30-lecia sądownictwa administracyjnego w Lublinie, Lublin 2013, s. 107-127.

${ }^{66}$ Wyrok NSA z dnia 6 lutego 1981 r., SA 819/80, ONSA 1981, nr 1, poz. 6.

${ }^{67}$ ONSA 1981, nr 2, poz. 70. 
Podobne podejście było konsekwentnie wyrażane także w innych wyrokach. Stanowisko to w późniejszym okresie potwierdził Trybunał Konstytucyjny. Ostatecznie znalazło ono odzwierciedlenie w Konstytucji RP z 1997 r. Wyjątkowe zasługi należy przypisać orzecznictwu Trybunału Konstytucyjnego i sądownictwa administracyjnego w sferze realizowania prawa do sądu, zarówno do 1997 r., jak i po uchwaleniu Konstytucji RP z 1997 r. W tym pierwszym okresie Trybunał, realizując prawo do sądu, wyraźnie poszerzał zakres tego prawa, a po wejściu w życie Konstytucji RP z 1997 r. prawo do sądu - wyrażone m.in. w art. 45 ust. 1 (wedle którego „Każdy ma prawo do sprawiedliwego i jawnego rozpatrzenia sprawy bez nieuzasadnionej zwłoki przez właściwy, niezależny, bezstronny i niezawisły sąd") - starał się maksymalnie doprecyzować.

Istotne w kontekście zasady demokratycznego państwa prawnego, urzeczywistniającego zasady sprawiedliwości społecznej oraz wyprowadzonej z niej, a także z preambuły do Konstytucji RP, miało być zwrócenie uwagi na funkcjonalność systemu organów administracji publicznej. W wyroku z dnia 7 stycznia 2004 r. w sprawie K 14/03 Trybunał Konstytucyjny orzekł, że:

Art. 36 ust. 1 ustawy z dnia 23 stycznia 2003 r. o powszechnym ubezpieczeniu w Narodowym Funduszu Zdrowia (Dz.U., nr 45, poz. 391, nr 73, poz. 660, nr 96, poz. 874, nr 122, poz. 1143, nr 128, poz. 1176 , nr 135, poz. 1268, nr 66, poz. 1609 , nr 202, poz. 1956 i nr 210, poz. 2037) w związku z przepisami tej ustawy dotyczącymi organizacji i zasad działania Narodowego Funduszu Zdrowia (rozdziały 1 i 4), zasad zabezpieczenia potrzeb zdrowotnych i organizacji udzielania świadczeń zdrowotnych (rozdziały 5, 6, 7 i 8), gospodarki finansowej (rozdział 9), zasad nadzoru i kontroli wykonywania zadań Narodowego Funduszu Zdrowia (rozdział 13), są niezgodne z art. 68 w związku z art. 2 Konstytucji Rzeczypospolitej Polskiej przez to, że tworząc instytucję publiczną w kształcie uniemożliwiającym jej rzetelne i sprawne działanie, naruszają zasady państwa prawnego w zakresie konstytucyjnego prawa obywateli do równego dostępu do świadczeń opieki zdrowotnej finansowanej ze środków publicznych ${ }^{68}$.

Wyrok ten był swoistym ewenementem, ponieważ Trybunał Konstytucyjny zakwestionował prawie całą ustawę z dnia 23 stycznia 2003 r. o powszechnym ubezpieczeniu w Narodowym Funduszu Zdrowia, mając na uwadze wyprowadzoną z preambuły dysfunkcjonalność rozwiązań prawnych tam zawartych, a przez to także jej sprzeczność z zasadą państwa prawnego, urzeczywistniającą zasady sprawiedliwości społecznej.

Trybunał Konstytucyjny w uzasadnieniu tego wyroku uznał, że ta dysfunkcjonalność w przypadku kwestionowanej ustawy przyjmuje różne oblicza, bowiem jest to: dysfunkcjonalność w zakresie ustroju administracyjnego i organizacyjnego systemu ochrony zdrowia, dysfunkcjonalność uniemożliwiająca sensowne powiązania organów państwa i jednostek samorządu terytorialnego z Narodowym Funduszem Zdrowia, dysfunkcjonalność systemu finansowania usług zdrowotnych ze

${ }^{68}$ Wyrok Trybunału Konstytucyjnego z dnia 7 stycznia 2004 r., sygn. akt K 14/03, OTK ZU 2004/1A/1. 
środków publicznych, dysfunkcjonalność będąca konsekwencją sprzeczności pomiędzy przepisami prawa i fikcyjności rozwiązań prawnych, dysfunkcjonalność w zakresie kompetencji i zadań poszczególnych organów oraz odpowiedzialności z nimi związanej, dysfunkcjonalność w zakresie dotyczącym nadzoru itd. Taki stan rzeczy w rozumieniu Trybunału Konstytucyjnego prowadzi do naruszenia elementarnych standardów państwa prawnego.

Wskazując na niektóre problemy związane z funkcjonowaniem zasady państwa prawnego, należy podkreślić, że nie wyczerpują one wszystkich zagadnień z nią związanych. Podkreślając znaczenie tej zasady, należy pamiętać, że ma ona wyjątkowe znaczenie dla kształtowania ładu publicznego w sferze materialnego prawa administracyjnego, postępowania administracyjnego i ustroju administracji publicznej. To, jaka jest rzeczywista siła jej oddziaływania na ład publiczny (prawny) w państwie, uzależnione jest nie tylko od jej zadeklarowania w Konstytucji, ale także, a może nawet przede wszystkim, od tego, w jaki sposób dookreśla się ją w praktyce stosowania prawa. Stąd pytanie o istotę państwa prawnego nigdy nie traci na aktualności, bo jest to zawsze pytanie o istotę prawa. Dążąc do optymalizacji formuły konkretnej filozofii państwa prawnego, trzeba mieć zawsze na uwadze to, czy nasze podejście do tej zasady prowadzi do tego, że prawo staje się sztuką tego, co dobre, słuszne, roztropne, racjonalne i sprawiedliwe. I tu należy stwierdzić, że swoistymi zagrożeniami dla optymalizacji zasady państwa prawnego mogą być takie zjawiska, jak: zwolnienie się z obowiązku poszukiwania sensu prawa, zamknięcie się w kręgu różnych schematów i formalnych mitów czy uwolnienie prawa od wartości.

Prawo, które dystansuje się od wartości - pisałem w artykule Drogi i bezdroża państwa prawnego - zbacza też z drogi, która prowadzi do prawdy. Świątynią prawa jest prawda. Co to za droga - pyta staruszka w znakomitym filmie Abuładze Pokuta, która nie prowadzi do żadnej świątyni...? Można też zapytać, co to za prawo, które nie prowadzi do prawdy ${ }^{69}$.

Niewątpliwie idei państwa prawa nie służy też: inflacja prawa i poszczególnych jego instytucji, przeciwstawienie wartości proceduralnych wartościom materialno-prawnym, uwolnienie prawa od wartości, nadmierny relatywizm w podchodzeniu do prawa itd. ${ }^{70}$ Zasada państwa prawnego winna być symbolem ujmowanego wielopłaszczyznowo ładu publicznego.

\section{PODSUMOWANIE}

Problematyka zasad prawa administracyjnego ma znaczenie fundamentalne, a zarazem wywołuje wiele sporów i dyskusji, które dotyczą: samego pojęcia

\footnotetext{
${ }^{69}$ M. Zdyb, Drogi i bezdroża..., s. 210.

${ }^{70}$ Zob. szerzej: ibidem, s. 197-235.
} 
„zasady prawa”, charakteru tych zasad, stopnia ich ogólności, ich funkcji, zadań i roli dla prawa administracyjnego, ich istoty czy też odpowiedniej klasyfikacji. W ramach niniejszego opracowania odniesiono się do wszystkich wymienionych kwestii, przy czym za wymagającą szczególnego wyróżnienia na gruncie prawa administracyjnego uznano zasadę państwa prawnego. Stanowi ona pomost między dobrem wspólnym i godnością człowieka, swoisty łącznik pomiędzy innymi zasadami ładu publicznego, który można ujmować w aksjologicznej perspektywie. Zasada ta jest jedną $\mathrm{z}$ aksjologicznych podstaw dla właściwej interpretacji zasad ogólnych kodeksu postępowania administracyjnego. Może też dawać podstawę do kreowania prawa do dobrej administracji. Ma ona wyjątkowe znaczenie dla kształtowania ładu publicznego w sferze prawa administracyjnego, a powinna także być symbolem ładu publicznego ujmowanego wielopłaszczyznowo.

\section{BIBLIOGRAFIA}

Adamiak B., Borkowski J., Postępowanie administracyjne a postępowanie cywilne - porównanie funkcji i zasad, [w:] Prawo. Administracja. Obywatele. Profesorowi Eugeniuszowi Smoktunowiczowi, red. B. Kudrycka, J. Mieszkowski, Białystok 1997.

Boć J., Cechy źródet prawa administracyjnego, [w:] Prawo administracyjne, red. J. Boć, Wrocław 2007.

Cieślak Z., Zasady prawa administracyjnego, [w:] Z. Niewiadomski (red.), Z. Cieślak, I. Lipowicz, G. Szpor, Prawo administracyjne, Warszawa 2007.

Engisch K., Einfuhrung in das juristische Denken, Stuttgart 1959.

Gadamer H.-G., Wahrheit und Methode, Tubingen 1975.

Gizbert-Studnicki T., Zasady i reguly prawne, „Państwo i Prawo” 1988, z. 3.

Kaufmann A., Rechtsphilosophie, Rechtstheorie, Rechtsdogmatik, [w:] Einfuhrung in Rechtsphilosophie und Rechtstheorie der Gegenwort, Heidelberg 1989.

Kmieciak Z., Ogólne zasady prawa i postępowania administracyjnego, Warszawa 2000.

Kordela M., Zasady prawa. Studium teoretycznoprawne, Poznań 2012.

Krąpiec M.A., Suwerenność, by ocalić, Toruń 1997.

Longchamps F., Z problemów poznania prawa, Wrocław 1968.

Łętowski J., Prawo administracyjne. Zagadnienia podstawowe, Warszawa 1990.

Mazurek F.J., Godność osoby ludzkiej podstawa praw czlowieka, Lublin 2001.

Olejniczak-Szałowska E., Pojęcie, cechy i typologia zasad prawa administracyjnego, [w:] Prawo administracyjne. Pojęcia, instytucje, zasady $w$ teorii i orzecznictwie, red. Z. Duniewska, B. Jaworska-Dębska, R. Michalska-Badziak, E. Olejniczak-Szałowska, M. Stahl, Warszawa 2013.

Pułło A., Z problematyki zasad prawa: idee ogólne w prawie konstytucyjnym, „Przegląd Sejmowy” 1996, nr 1(13).

Radbruch G., Die Natura der Sache als juristische Denkform, Dormstadt 1960.

Stahl M., Wpływ zasad ogólnych na przeksztatcenia ustrojowe w administracji publicznej. Zagadnienia wybrane, [w:] Ewolucja prawnych form administracji publicznej. Ksiega jubileuszowa z okazji 60. rocznicy urodzin Profesora Ernesta Knosali, red. L. Zacharko, A. Matan, G. Laszczyca, Warszawa 2008. 
Stahl M., Zasada demokratycznego państwa prawnego, [w:] Prawo administracyjne. Pojęcia, instytucje, zasady w teorii i orzecznictwie, red. Z. Duniewska, B. Jaworska-Dębska, R. MichalskaBadziak, E. Olejniczak-Szałowska, M. Stahl, Warszawa 2013.

Starościak J., Źródła prawa administracyjnego. Zasady ogólne prawa administracyjnego, [w:] System prawa administracyjnego, red. J. Starościak, t. 1, Wrocław 1977.

Szreniawski J., Prawo administracyjne. Część ogólna, Lublin 1994.

Święcki J.S., Przepisy ogólne prawa administracyjnego jako problem badawczy $w$ teorii prawa administracyjnego, [w:] Nowe problemy badawcze w teorii prawa administracyjnego, red.

J. Boć, A. Chajbowicz, Wrocław 2009.

Ura E., Ura E., Prawo administracyjne, Warszawa 1999.

Wronkowska S., Ziembiński Z., Zarys teorii prawa, Poznań 2001.

Wróblewski J., Prawo obowiąujące a „ogólne zasady prawa”, „Zeszyty Naukowe Uniwersytetu Łódzkiego. Nauki Humanistyczno-Społeczne. Seria I" 1965, z. 42.

Wyrok NSA z dnia 6 lutego 1981 r., SA 819/80, ONSA 1981, nr 1, poz. 6.

Wyrok NSA z dnia 20 lipca 1981 r., ONSA 1981, nr 2, poz. 70.

Wyrok TK z dnia 7 stycznia 2004 r., sygn. akt K 14/03, OTK ZU 2004/1A/1.

Zasady ustroju III Rzeczypospolitej Polskiej, red. D. Dudek, Warszawa 2009.

Zdyb M., Drogi i bezdroża państwa prawnego, [w:] Konstytucja, ustrój, system finansowy państwa. Księga pamiatkowa ku czci Prof. Natalii Gajl, Warszawa 1999.

Zdyb M., Ksztaltowanie standardów demokratycznego państwa prawnego w orzecznictwie sadowoadministracyjnym, [w:] Księga jubileuszowa z okazji 30-lecia sadownictwa administracyjnego w Lublinie, Lublin 2013.

Zdyb M., Państwo prawa w perspektywie zaszłości historycznych oraz dokonujących się zmian, [w:] Wspótczesne problemy prawa publicznego, red. S. Fundowicz, Lublin 1999.

Zdyb M., Prawny interes jednostki w sferze materialnego prawa administracyjnego. Studium teoretyczno-prawne, Lublin 1991.

Ziemski K., Zasady ogólne prawa administracyjnego, Poznań 1989.

\section{SUMMARY}

The problems connected with an issue of the principles/rules of administrative law are of great importance and - at the same time - cause lots of controversies and discussions relating to the notion of "principles/rules of law" itself, the character (nature) of these principles, the degree of their general character (their generality), their functions, tasks and their importance for administrative law, their essence or their proper classification. Within this scientific description all these problems were presented, whereas the principle of the state of law was chosen to be particularly distinguished on the basis of administrative law. This principle is a platform between common good and the dignity of the individual, specific link (connecting factor) between other principles of public order which can be formulated in axiological perspective. The principle of the state of law is one of the axiological basis for proper interpretation of the general principles of the code of administrative procedure. It can also give the ground for creating the right to good/sound administration. This principle is of great importance for shaping the public order in the sphere of administrative law (and - still more important - for shaping the legal position of administered subjects) and likewise it should be the symbol of public order formulated on many planes.

Keywords: state of law; public order; common good; dignity of the individual; the right to good/sound administration 